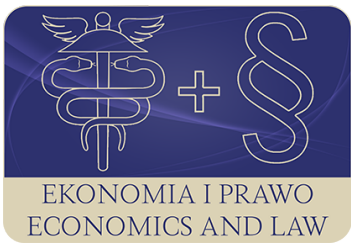

EKONOMIA I PRAWO. ECONOMICS AND LAW

Volume 20, Issue 1, March 2021

p-ISSN 1898-2255, e-ISSN 2392-1625

www.economicsandlaw.pl

ORIGINAL ARTICLE

received 20.11.2020; revised 20.03.2021; accepted 31.03.2021

Citation: Borkowski, M. (2021). The quality of formal institutional subsystems of OECD countries.

Ekonomia i Prawo. Economics and Law, 20(1): 21-44. doi:10.12775/EiP.2021.002.

\title{
The quality of formal institutional subsystems of OECD countries
}

\author{
MATEUSZ BORKOWSKI \\ University of Bialystok, Doctoral School in the Social Sciences, \\ ul. Warszawska 63, 15-062 Białystok, Poland \\ $\square$ m.borkowski@uwb.edu.pl \\ (D) orcid.org/0000-0003-0644-4764
}

\begin{abstract}
Motivation: Institutions are the core element of every economic system. Institutions condition all economic, social and political relations within the economy. They are universal. There is no doubt that a non-institutional analysis of contemporary economies is incomplete. The subject of this article are subsystems of formal institutions of OECD countries. This paper is an attempt to supplement contemporary economics with a structural model of formal institutional environments.

Aim: The purpose of the article is to assess the quality of formal institutions of OECD economies and to identify the most important groups of institutions that shape the formal institutional environment of modern economies. A research hypothesis was adopted, stating that the quality of property rights has the strongest positive impact on the quality of formal institutional subsystems.

Results: The analysis of the literature allowed the indication of the importance of (especially formal) institutions in the economy. The constructed soft model allowed for positive hypothesis verification. As it turns out, the quality of formal institutions is positively influenced by all three separate groups of formal institutions, but institutions of property rights are of the greatest importance.
\end{abstract}

Keywords: institutional economics; formal institutions; soft model; SEM-PLS JEL: C31; C38; E02; O43; P37 


\section{Introduction}

Institutions are the core of every economic system. There is no doubt that "institutions matter" (North, 1990). Institutions condition all economic, social and political relations in the economy. They are universal. There is no point in analyzing contemporary economies disregarding the institutional approach.

The subject of this article are subsystems of formal institutions of OECD countries. The article analyses the institutions at the macroeconomic level. This paper is an attempt to supplement contemporary economics with a structural model of formal institutional environments.

The aim of the article is to assess the quality of formal institutions of OECD economies and to identify the most important groups of institutions that shape the formal institutional environment of modern economies. As part of the considerations, a research hypothesis was adopted, stating that the quality of property rights has the strongest positive impact on quality of formal institutional subsystems. The year 2017 was selected as the period of research, due to it being the most recently available statistical data.

The quality of institutions was measured using aggregative indexes developed by selected statistical organisations such as: The Fraser Institute (2020), The Heritage Foundation (2020), Property Rights Alliance (2020) and The World Bank (2020). In order to achieve the aim of the article, the soft modelling method (PLS-SEM) was applied. The soft model was estimated using the R computing environment - plspm $^{1}$ and SEMpls ${ }^{2}$ packages were used. Additional calculations were performed in a MS Excel.

\section{Institutions in contemporary economies}

Defining institutions is not an easy task. The difficulty of precisely determining what this term means is due to its interdisciplinary and multidimensional nature. An additional difficulty is the fact that institutions are not directly observable, they are invisible (Wilkin, 2016, p. 99).

The concept of institutions has its origins long before the emergence of economics as a science (Hodgson, 2006, p. 2). In economic theory, the exploration of institutions has lasted since the times of classical economics (Gruszewska, 2013a, p. 99). Already A. Smith, both in the Theory of moral sentiments and An inquiry into the nature and causes of the wealth of nations included institutional issues of the functioning of the economy (Tajima, 2007, p. 579). The particular development of economic theory in the field of institutions took place at the beginning of the 20th century thanks to Veblen (2016, p. 88), who understood institutions as a kind of custom that became obvious and universally accepted (Veblen, 1924, p. 101). The "father" of institutionalism emphasised that institu-

\footnotetext{
${ }^{1}$ Developed by Sanchez et al. (2014).

${ }^{2}$ Developed by Monecke \& Leisch (2012).
} 
tions are the product of past socio-economic processes. They are ideally suited to the past, but will never be fully in line with the conditions of the present.

According to North $(1990$, p. 1), a representative of new instructional economics (NIE), institutions are the "rules of the game", which are created by people. They shape interpersonal interactions and stimulate exchanges of an economic, political or social nature. Just like Veblen he emphasised the importance of the past in the creation and change of existing institutions ${ }^{3}$. North (1990, p. 118) claimed that institutions are the "bridge" between the past, present and future.

There are three main approaches to institutions in economic theory (Gancarczyk, 2002, p. 82). First of all, institutions are recognised as a system of interdependent, formal and informal, rules and customs. Secondly, they are identified with organisations ${ }^{4}$. Lastly, the third approach defines institutions as a state of equilibrium in the game $e^{5}$. This article uses a process approach to institutions that clearly separates them from organisations (entities).

In this article, the definition proposed by Hodgson (2006, p. 18) is adopted, according to which institutions are a system of established and embedded principles (rules) that influence economic, social and political interactions.

The importance of institutions in the economy is indisputable. Institutions are universal - they regulate economic, political and social relations (Vitola \& Šenfelde, 2015, p. 278). They give meaning to entities, create a safe area of economic interactions, and thus contribute to increasing the predictability of the behaviour of individuals. However, it seems that the most important function of institutions is to define acceptable solutions, create opportunities, but also to define the boundaries of the functioning of entities (Gruszewska, 2013a, p. 136).

Scheme 1 graphically presents the effect of the implementation and evolution (development) of institutions in the economy. In conditions of uncertainty and high transaction costs, the introduction or appropriate modification of institutions contributes to the increase in the predictability of the individuals' behaviour, which in turn leads to the creation of a relatively safe field of interaction, an increase in environmental stability and a reduction in transaction costs (Iwanek \& Wilkin, 1997, p. 19).

In order to positively influence the activity of individuals in society, institutions need to meet several conditions (Wang, 2002, p. 137). First, they should clearly state the costs, but also the benefits of the choices (institutions must be understandable). Secondly, the institutions' task is to define "the rules of the game" - ex ante restrictions. What is more, institutions must establish

${ }^{3}$ North (1994b, p. 386) pointed out that institutions strongly depend on the past ("path dependence concept").

4 This approach is used in neoclassical economics and also in everyday language. Some representatives of institutional economics also use this meaning of institutions, for example Williamson (1985) who equated corporations with institutions.

5 This approach is characteristic especially for Aoki (2000). 
sanctions in case of the deviant behaviour of individuals. The sanctions should be severe enough to reduce the benefits for individuals disobeying "the rules of the game" (Gruszewska, 2013a, p. 109). Moreover, institutions have to be characterised by completeness and the mutual relations of: complementarity ${ }^{6}$ and substitutability ${ }^{7}$ (Bardhan, 2005, p. 521).

Changes are an inherent process of every institutional system. They consist of "constant «clashes» of the rules and their adaptation to social interactions" (Gruszewska, 2017, p. 41). The dynamics of institutional changes are varied they depend on the type and nature of the institution (Chang \& Evans, 2005, pp. 6-8). The evolution of the institutional structure should progress towards building so-called "good" institutions (Rodrik, 2007, p. 153). "Good", i.e. those that improve the flow of information, protect property rights and contracts, and stimulate the behaviour of market participants (Gruszewska, 2013a, p. 157). Efficient institutions are of particular importance to the economic growth and development. The quality of institutions is considered to be one of the deep factors of the growth (Rodrik et al., 2004, pp. 133-134). Alongside institutions, geographical determinants and the openness of the economy are considered to be fundamental growth causes (Acemoglu, 2009, pp. 114-123).

The quality assessment of institutions consists in the analysis of measures of institutional quality developed by international statistical organisations (Kunčič, 2014, p. 143). Such measures are quite often used in institutional analysis. They are also subject to criticism, so the interpretation of the obtained results should be approached with great caution (Voigt, 2013, pp. 15-22). It should be noted that the measures are only a certain approximation of reality, not its exact representation.

Worldwide Governance Indicators (WGIs) are some of the most commonly used in institutional research. They consist of six synthetic variables: voice and accountability, political stability and absence of violence, government effectiveness, regulatory quality, rule of law and control of corruption. Each variable is a stimulant in nature, meaning that higher values indicate higher institutional quality (Kaufmann et. at., 2011). WGIs are commonly used in institutional analysis, for example: Ferrara \& Nisticò (2019), Shchegolev \& Hayat (2018), Wu (2017). Measures of institutional quality also include indicators developed by The Fraser Institute (Economic Freedom in the World - EFW). EFW variables are estimated on the basis of experts' assessments, and include five areas: size of government, legal system and property rights, sound money, freedom to trade internationally and regulation. They are also, just like WGIs, stimulants of institutional quality and used for the analysis of institutional structure, for example: Balcerzak (2020), Medina-Morala \& Montes-Gan (2018). A third

${ }^{6}$ Institutions should be surrounded by other institutions that complement them (Höpner, 2005, p. 333).

7 Substitution consisting in displacing outdated institutions with new ones, which are of a higher quality (Gruszewska, 2011, p. 55) and better suited to the conditions of the present. 
international statistical organisation which provides institutional quality data is The Heritage Foundation. Their Index of Economic Freedom (IEF) includes four main components: rule of law, government size, regulatory efficiency and open markets. Higher values of IEF variables indicate a higher efficiency of institutions. IEF was used in Murphy (2016), Ott (2018), Procházka \& Čermáková (2015). Property rights quality can be measured using detailed measures prepared by Property Rights Alliance. The International Property Rights Index (IPRI) assesses formal institutional systems in three spheres: legal and political environment and the quality of physical and intellectual property rights. Examples of the use of these indicators can be found in the works Howard-Hassmann (2013), Koroso et. al. (2019), Owczarczuk (2013).

To measure the efficiency of formal institutional subsystem elements, selected synthetic variables of institutional quality developed by the described statistical organisations were applied. The higher institutional measures (also latent variables) values are, the higher the quality of the institution is.

It should be emphasised that the high efficiency of an institution leads to the creation of conditions enabling the achievement of social and economic benefits for all individuals in society. The quality of the institution, or rather the lack of it, becomes an instrument of explaining the development inequalities of contemporary economies (Myrdal, 1978, pp. 773-775). As Ratajczak (2011, p. 41) aptly points out, in order for economics not to be perceived as a science detached from reality, it must take into account the importance of institutions. It seems that the analysis of changes in contemporary economies is not possible without the aid of institutional economics (Ciborowski et al., 2017, p. 9).

\section{Formal institutional subsystem}

There are many classifications of institutions within contemporary institutional theory. Divisions according to D.C. North, F.A. Hayek, J. Jütting and O. E. Williamson are presented in Scheme 2. Formal institutions, alongside informal ones, constitute the institutional structure of the economy. Informal institutions include: culture, religion, patterns of behaviours, social trust and "mental models" (Fiedor, 2015, p. 100). There are numerous classifications of formal institutions. For example, North (1994a, p. 360) lists: rules, laws and constitutions as components of formal institutional subsystems. According to Williamson (2000, p. 597) these are: formal rules of the game, politics (and property), bureaucracy and management mechanisms. Dobler (2011, p. 15) distinguishes property rights, the legal system (the rule of law) and democracy within the subsystem of formal institutions.

In this article the classification proposed by Fiedor $(2015$, p. 100) is applied. The subsystem of formal institutions consists of: legal order, property rights and various types of regulations (e. g. monetary, labour market, real estate market or business). 


\subsection{Legal order}

The law is a set of norms that can be enforced by courts. It is a system of established rules, the purpose of which is to regulate governments and define the relations between the state and its individuals, and between the individuals themselves (Dworkin, 1967, pp. 18, 40). Law is considered to be the core of not only social (Zhuravlev, 2017), but also economic life (Faundez, 2016, p. 34). Institutions of a legal order are the basis of formal institutional environment - they affect both the shape of property rights ${ }^{8}$ and the quality of regulations.

The legal order must be generally recognised as reasonable, appropriate and fair. The law must be adapted to customs embedded in society (Deakin et al., 2017, p. 190). Fuller (1969, as cited in Kwaśnicki, 2009, p. 133) indicates eight features that the law should meet in order to have a positive impact on socio-economic processes (Rossmanith, 2019, p. 135):

- generality, impartiality;

- promulgation of legal acts (common knowledge and accessibility of the law);

- prospectivity;

- clarity and transparency;

- non-contradiction of legal provisions;

- feasibility;

- stability;

- compliance between the activities of state organizations with applicable law. The quality of a legal order institution depends on the rule of law. According to Dicey (1979, p. xxii), the rule of law means: equality of all individuals in society before the law, uniformity of courts, inadmissibility of raison d'état as a pretext for an act prohibited by law, domination of law over state power (Kwaśnicki, 2009, p. 132), and adherence to the nullum crimen sine lege principle (no crime without law).

\subsection{Property rights}

Property is a relationship between individuals who have rights but also obligations with respect to things (Commons, 1924). Property rights are the institution that defines and delimits the privileges held by individuals over resources (Boudreaux, 2005, p. 4). They are considered as a social instrument which allows and helps to shape expectations that an individual can maintain in contacts with the others (Demsetz, 1974, p. 347).

Property rights are strongly embedded in the existing institutional setup, which includes both formal and informal institutions (Cao, 2012, p. 286). The institutions of property rights mainly take on a formal character, as rights contained in the constitution, laws and other legal regulations (Boudreaux \& Aligica, 2008, pp. 40-42). They are a series of related rights of the resource

8 If property rights institutions are not be secured by appropriate law (legal order), they would not exist (Dobler, 2011, p. 71). 
owner and others to whom some of these rights may be transferred (Gruszewska, 2020, p. 49). Schlager \& Ostrom (1992, pp. 251-252) indicate five basic rights connected to property:

- access - the right to access and use the owned resource;

- withdrawal - the right to receive benefits due to the use of a resource at the same time depriving other individuals of the possibility of using the resource;

- management - the right to determine how to use and improve the possessed resources;

- exclusion - the right to decide who can also use the resource;

- alienation - the right to sell, lease or sublease selected property rights.

Only the "full owner" has access to all the listed property rights. Access to selected property rights may also be transferred to other entities, depending on the position in relation to the "full owner" (Gruszewska, 2020, p. 50). Ostrom (2003) created a matrix of property rights that are associated with a position to the "full owner" (Table 1).

The importance of property rights in contemporary economies is indisputable. Boudreaux (2005, pp. 11-16) lists four basic functions of the property rights institutions:

- helping individuals to allocate their resources efficiently;

- creating positive incentives for example to: invest, create, be innovate or save money (Williamson, 2011, p . 97);

- supporting economic development and removing income inequalities (contribution to reducing poverty);

- determining the level or socio-economic welfare ("human flourishing and empowerment").

\subsection{Regulatory institutions}

Regulatory institutions are the third element of the formal institutional subsystem. Regulation is understood as a process that involves modifying alternatives, outputs, technologies, information and other elements that influence the decisions of individuals (Riker \& Ordeshook, 1973). It is a kind of social control carried out by introducing principles and rules in the form of legal and administrative acts (Levi-Faur, 2010, pp. 4-5). The quality of legal order institutions significantly influences regulatory institutions in the economy.

The existence of market mechanism distortions is the reason for regulation (Rodrik, 2007, p. 157). The most common market failures include (Stiglitz, 2000, pp. 77-85): the presence of monopolies (competition distortion), asymmetric information between entities, externalities (especially external costs), the occurrence of public goods provided by public sector, unemployment and other disruptions of a macroeconomic nature (such as inflation or economic underdevelopment). These are economic market failures. Ogus (2002, p. 629) 
mentions non-economic market mechanism distortions: distributional injustice and paternalism.

The basic classification of regulations divides them into economic and social (Aktan, 2016, p. 306). Economic regulations are related to categories such as efficiency, effectiveness and competition. Their basic task is to eliminate market mechanism inefficiencies. Social regulations perform two basic functions in the economy: they correct socially harmful effects of economic activity and lead to the achievement of socially desirable results (Windholz \& Hodge, 2012, pp. 220-224).

De Rosa \& Malyshev (2008, p. 12) list five basic groups of regulations that are of fundamental importance in every economy, which are:

- competition protection (elimination of anti-competitive behaviour);

- access regulation (excluding discrimination in access);

- economic regulation (price regulations, consumer protection);

- technical regulations (safety and environmental regulations);

- introducing periodic corrective regulations.

\section{Research method: soft modelling (SEM-PLS)}

Soft modelling (SEM-PLS) is a method which was created by Wold (1980a, 1980b). It is a specific type of econometric modeling', in which there are two kinds of "softness": observational (measuring latent variables using a set of observable indicators) and distributional (no need to determine multidimensional distribution ex ante) (Skrodzka, 2015, p. 59). SEM-PLS is an alternative method to traditional covariance based SEM-CB. The biggest advantage of structural equation modelling (SEM) is that it strongly combines empirics with theory (Skrodzka, 2016, p. 283). SEM-PLS, unlike SEM-CB, allows for the estimation of latent variable values that can be used for linear ordering of objects (observations) in terms of the latent variable and that is why this method was chosen for this research (Hair et. al., 2017, pp. 14-15).

Every soft model consists of two sub-models: an inner (theoretical) and an outer (measurement) one. The theoretical model describes the relationships between latent variables, while the measurement one defines the relations between the hidden variables and their explanatory indicators (Ciborowski \& Skrodzka, 2019, p. 389).

Latent variables can be defined in two different ways: deductively (when the latent variable is primary in relation to its diagnostic variables) and inductively. Under the deductive approach, the observable indicators are reflective, while in the inductive analysis, they are formative (Perło, 2014, p. 255). In this article the deductive approach is applied ${ }^{10}$.

9 A detailed description, generalizations and empirical applications can be found in: Perło (2014), Rogowski (1990) and Sanchez (2013).

10 The external model analysis is mainly based on factor loadings, not weights (Marcinkiewicz, 2013, p. 456). 
The selection of diagnostic variables was carried out on the basis of substantial and statistical criterions ${ }^{11}$. From a set of twenty-one diagnostic variables, fifteen were selected for input into the final model ${ }^{12}$ (Table 2). Each of selected measure is a stimulant, which means that its higher values indicate a higher quality of the institutions.

A diagram of the soft model applied in the study is presented in Scheme 3. The soft model of the quality of formal institutions consists of four latent variables and thirty directly observable indicators.

LEG (the quality of legal order institutions), PR (the quality of the institution of property rights), and REG (the quality of regulatory institutions) are first level latent variables. The FORM (the quality of formal institutional subsystems) is the second level latent variable (Table 2). The paper assumes that explanatory indicators of the FORM variable are all the observable variables of lower-level latent variables with which this hidden feature remains in an internal relation (Misiewicz et. al., 2019, p. 6).

According to the diagram presented in Scheme 3, the theoretical sub-model is in the form of three stochastic equations $(1-3)$.

$$
\begin{aligned}
& P R_{t}=\alpha_{1} L E G_{t}+\alpha_{2}+\varepsilon_{1 t}, \\
& R E G_{t}=\beta_{1} L E G_{t}+\beta_{2}+\varepsilon_{2 t}, \\
& F O R M_{t}=\gamma_{1} L E G_{t}+\gamma_{2} P R_{t}+\gamma_{3} R E G_{t}+\gamma_{4}+\varepsilon_{3 t},
\end{aligned}
$$

where:

$\alpha_{n}, \beta_{n}, \gamma_{n}-$ structural parameters;

$t$ - year;

$\varepsilon_{e t}$ - random element of the e-equation.

In the outer model, there are two types of relationships between latent variables and their explanatory indicators: weighting and reflective. The first one assumes that a latent variables are linear combinations of their explanatory measures (4). On the other hand, the reflective relation represents the power of "reflecting" an unobservable measure by its explanatory variables (5) (Perło, 2014, pp. 88-89).

$$
\begin{aligned}
& \wedge_{j=1, \ldots, k} \wedge_{t=1, \ldots, T} \xi_{j t}=\sum_{i=1}^{n_{j}} W_{i j} X_{i j t}, \\
& \wedge_{j=1, \ldots, k} \wedge_{t=1, \ldots, T} X_{i j}=\pi_{i j 0}+\pi_{i j} \xi_{j t}+\mu_{i j t},
\end{aligned}
$$

${ }^{11}$ Statistical and substantive criterions: recognised importance and meaning, variability (classic coefficient of variation at the level above 5\%) and presentation in the form of intensity indicators (all selected variables are aggregative measures) (Borkowski, 2020, p. 101).

12 The selected set of indicators guarantees the best quality of the soft model (the highest values of: the determination coefficients and the Stone-Geisser tests). 
where ${ }^{13}$ :

$\xi_{j t}$ - value of the $j$-latent variable;

$x_{i j t}-t$-value of the diagnostic variable of the $j$-latent variable;

$w_{i j}$ - weight of the $i$-diagnostic variable of the $j$-latent variable;

$\pi_{i j 0}$ - location parameter of the reflective relation;

$\pi_{i j}$ - factorial loading of the $i$-diagnostic variable of the $j$-latent variable;

$\mu_{i j t}$ - random component of an expected value equal to zero.

The estimation of the soft model is performed using the partial least squares (PLS) procedure and takes place in three successive stages (Perło, 2014, p. 93):

1. First, an iterative estimation of weight values takes place. At this stage, a decision is made on the scheme for estimating the internal values of latent variables. As part of the modelling carried out in the article, the centroid ${ }^{14}$ formula was adopted.

2. Next, parameters (OLS regression) of the theoretical and measurement models are estimated. In the outer sub-model, parameters are factor loadings, but in the inner sub-model, they are a simple (in the case of one exogenous latent variable) or multiple ${ }^{15}$ OLS regression estimates.

3. The last stage is to estimate location parameters of both internal and external relations. To estimate intercepts, it is crucial to restore the original metrics by dividing weight and multiplying factor loading values by the appropriate standard deviation. The estimation follows the principles of "classical" econometrics ${ }^{16}$, assuming that the mean value of the latent variable takes the form (6) (Rogowski, 1990, p. 45):

$$
\bar{\xi}_{J}=\sum_{i=1}^{n_{j}} W_{i j} \bar{X}_{i j} \text {, }
$$

In the soft model, the nature of connections, both in the internal and external submodels, is linear (Misiewicz, 2013, p. 196). As a result of the PLS method, the values of hidden variables for objects are estimated. They can be treated as values of a synthetic indicator that are used to build a ranking of objects (e. g. OECD countries) in terms of a specific hidden structure. Importantly, estimates of latent variables for objects do not have a substantive interpretation they can mainly be used for comparative analysis based on the order of the objects (Mierzyńska, 2011, p. 293).

13 Equations' symbols on the basis of Lohmöller (1989, pp. 28-29) and Rogowski (1990, pp. 36-37).

14 The centroid formula was originally proposed by Wold, while the factorial and path schemes are a modifications of the PLS method introduced by J.-B. Lohmöller (Esposito Vinzi et al., 2010, p. 53).

15 Multiple OLS regression parameters of the inner model allows to verify adopted research hypothesis. Higher values of the structural parameter indicates a stronger impact on the latent variable.

16 Formulas for calculating location parameters can be found in Lohmöller (1989, p. 31) or Wold (1980b, p. 338). 
The verification of the soft model should be substantive and statistical in nature. As part of the substantive verification, the compliance of the estimation results with the initial assumptions is analyzed. In addition, the directions of the stimulant and destimulant signs are assessed (Perło \& Roszkowska, 2017, p. 7l). Various measures of the estimation quality are used for statistical verification. The article applies the following measures of statistical validation (Sanchez, 2013):

- one-dimensionality coefficients: Cronbach's alpha and Dillon-Goldstein's rho (so-called: Jöreskog's rho) ${ }^{17}$;

- determination coefficients $\left(\mathrm{R}^{2}\right)$.

Moreover, using the blindfolding method ${ }^{18}$, the following will be calculated (Rogowski, 1990, pp. 47-54):

- values of the Stone-Geisser test (S-G) (Akter et al., 2011; Sellin \& Versand, 1995, p. 262);

- parameters' standard deviations using Tukey's Jackknifing method.

The assessment of the predictive ability of the model is based on the StoneGeisser test (Geisser, 1974; Stone, 1974). The test takes values between $-\infty$ and 1. Negative values indicate that the estimated model has poor prediction abilities (Rocki, 1998, p. 110). It is the basis for negative model verification. While calculating $S-G$ test values, one can estimate the standard deviations of the model parameters using Tukey's Jackknifing ${ }^{19}$ method (Miller, 1974). For this purpose, the formula (7) was used (Rogowski, 1990, pp. 53-54). A parameter is statistically significant if its standard deviation does not constitute more than $50 \%$ of its estimated value - so-called the " $2 \mathrm{~s}$ " rule (Perło, 2014, p. 97).

$$
s_{\beta}=\sqrt{\frac{\sum_{l=1}^{L}\left(b_{l}-\bar{b}\right)^{2}}{L}} ; \bar{b}=\frac{\sum_{l=1}^{L} b_{l}}{L},
$$

where:

$b_{l}$ - value of the estimator of the selected soft model parameter (weight, factor loading);

$L$ - tested distance.

17 The Cronbach's alpha and Dillon-Goldstein's rho take values in the range of $<0,1>$. Values higher than 0.7 identify that set of indicators for the latent variable to be homogenous. Homogeneity coefficients can be only used in the deductive approach of defining latent variables in the model.

18 The blindfolding method consists in deleting every L-th value of the variable of a selected latent variable and replacing it with a "forecast" (e. g. arithmetic mean of the remaining variables). The procedure is repeated until each observation is predicted at least once. The number L (distance) is chosen arbitrarily. L was assumed in the study at the level of 7 . In the literature, it is recognised that the distance should be in the range between 5 and 10, $\mathrm{L} \in\{Z\}$ (Chin, 2010, p. 680).

19 The significance of parameters in the soft model can be also verified using the bootstrapping method (Davison \& Hinkley, 1997). 


\section{Results}

The estimation of the external model is presented in Table 3. Weights and factor loadings are statistically significant, in accordance with the " $2 \mathrm{~s}$ " rule. According to the measurement model, all the explanatory indicators are stimulants. The outer model parameters are consistent in terms of signs. The correctness of the selection of variables for latent structures is confirmed by high values (above 0.700 ) of Cronbach's alpa and Dillion-Goldstein's rho (Table 4).

Four variables $\left(\mathrm{L}_{2}\right.$ - judicial independence, $0.961 ; \mathrm{L}_{1}$ - rule of law, 0.955; $\mathrm{L}_{3}$ - impartial courts, $0.929 ; \mathrm{L}_{4}$ - integrity of the legal system, 0.836 ) are strongly correlated with the LEG latent variable. Only one of LEG variables $\left(\mathrm{L}_{5}\right.$ - judicial effectiveness, 0.630) reflected its values quite strongly. A similar situation occurs in the case of the PR latent variable. Four diagnostic indicators $\left(\mathrm{P}_{3}-\right.$ property rights protection, $0.980 ; \mathrm{P}_{1}-$ protection of property rights, 0.975; $\mathrm{P}_{4}$ - physical property rights protection, $0.927 ; \mathrm{P}_{5}$ - intellectual property rights protection, 0.921 ) have a very strong impact on shaping the $\mathrm{PR}$ values. Between the $\mathrm{PR}$ and the $\mathrm{P}_{2}$ - property rights, 0.665 - a strong correlation is observed. The quality of regulatory institutions (REG) latent variable is strongly correlated with three variables $\left(\mathrm{R}_{2}\right.$ - regulatory quality, 0.966; $\mathrm{R}_{1}$ - government effectiveness, $0.939 ; \mathrm{R}_{5}$ - business regulations, 0.860), while quite strongly with other two $\left(\mathrm{R}_{3}\right.$ - sound money, $0.689 ; \mathrm{R}_{4}$ - labour market regulations, 0.573$)$. The FORM measure, which is a second-order latent variable, is strongly correlated with eleven observable variables, quite strongly with three, and moderately with one.

The estimated equations of the theoretical model are presented in the form of formulas (8-10). The standard deviations of the structural parameters calculated using the Tukey's Jackknifing method are presented in brackets. All parameters are statistically significant (" $2 s$ " principle). The inner model is considered to be coincident.

$$
\begin{aligned}
& P R_{2017}=\underset{(0.006)}{0.948} L E G_{2017}+\underset{(0.230)}{3.497,(8)} \\
& \mathrm{R}^{2}=0.899 ; \mathrm{S}-\mathrm{G}=0.700 ; \\
& R E G_{2017}=\underset{(0.013)}{0.942} L E G_{2017}+\underset{(0.230)}{5.451,(9)} \\
& \mathrm{R}^{2}=0.887 ; \mathrm{S}-\mathrm{G}=0.540 ; \\
& F O R M_{2017}=\underset{(0.048)}{0.342 L E G_{2017}}+\underset{(0.037)}{0.370} P R_{2017}+\underset{(0.063)}{0.311} R E G_{2017}+\underset{(0.293)}{0.026,(10)} \\
& \mathrm{R}^{2}=1.000 ; \mathrm{S}-\mathrm{G}=0.680 .
\end{aligned}
$$

Equation (8) shows that the quality of legal order institutions has a very strong, positive (0.948) impact on the quality of property rights. The variability of the PR is approximately $90 \%$ explained by the variability of the LEG. 
The value of the S-G test is equal to 0.700 ; which proves a good predictive ability of this latent structure.

Legal order institutions also have a very strong positive (0.942) impact on shaping the quality of regulation (9). The equation is adjusted to the empirical data at a high level $\left(\mathrm{R}^{2}=0.887\right)$. The latent variable $\mathrm{REG}$ has quite good predictive abilities $(S-G=0.540)$.

Equation (10) presents the main function of the article. The strength and direction of the influence of individual institutions on the quality of the formal institutional subsystem is similar, but it is property rights that have the strongest influence on the FORM latent variable shaping. On this basis, the adopted hypothesis can be positively verified. The quality of the equation is ideal (the coefficient of determination is at 1.000). The overall value of the $S-G$ test is at the level of 0.680 , which indicates good model predictive abilities.

The soft model describing the quality of formal institutions of OECD countries is considered to be positively substantially and statistically verified.

Rankings of OECD countries according to values of latent variables are presented in Table 5. The objects are classified into four typology groups using the mean and standard deviation ${ }^{20}$.

In 2017 the highest quality of legal order institutions are in Finland, while the lowest are in Mexico. The best protected property rights are also found in Finland, and the least protected in Greece. The economy having the highest quality of regulatory institutions is New Zealand, while of the lowest can be found in Mexico. The highest value of the FORM latent variable is in Finland, while the lowest is in Greece.

The group of economies with the highest quality of formal institutions includes four countries: Finland, Switzerland, New Zealand and the Netherlands. The six countries with the lowest quality of formal institutional subsystems are: Slovakia, Poland, Italy, Turkey, Mexico and Greece. It seems that in these countries formal institutions are not pro-developmental. One can even say that their low quality is a kind of a barrier to the dynamics of economic processes.

\section{Conclusion}

The main purpose of the article was an attempt at a multidimensional assessment of the quality of the formal institutional environment of OECD countries. The aim of the study was achieved with the use of the soft modelling method (SEM-PLS). By analysing much the literature on the topic of the social sciences, it was possible to indicate the importance of institutions in economies. It was emphasised that a contemporary macroeconomic analysis should, or one could even say must, include an institutional analysis.

The estimated soft model of the quality of formal institutions of OECD economies provided many conclusions, but, most importantly, allowed for a positive

20 The indicators are standardised, which means that the mean is equal to 0 , and the standard deviation to 1 (Ciborowski \& Skrodzka, 2019, p. 399). 
verification of the adopted research hypothesis. As it turns out, the quality of formal institutions is strongly, positively influenced by all three separate groups of formal institutions, but the institutions of property rights are of the greatest importance. The internal model also allowed for the conclusion that legal order institutions have a very strong positive influence on shaping the quality of the property rights and regulatory institutions.

Values of latent variables were used to rank OECD countries in 2017 in terms of the quality of formal institutions. Finland seems to be the economy with the most prosperous formal institutional environment. In 2017 the weakest formal institutional subsystem is in Greece.

Institutions should become a "routine" in researching economic processes. They are the core of every socio-economic structure. Not only does the quality of these institutions have a direct impact on economic growth itself, but also on its determining factors (deep growth determinants).

The article is the beginning of author's considerations on institutions in modern economies. Subsequent studies assume an analysis of the informal institutional environment, with a particular emphasis on economic culture institutions.

\section{References}

Acemoglu, D. (2009). Introduction to modern economic growth. Princeton: Princeton University Press.

Aktan, C.C. (2016). Regulatory public policies: an introductory survey. International Journal of Economics and Finance Studies, 8.

Akter, S., D'Ambra, J., \& Ray, P. (2011). An evaluation of PLS based complex models: the roles of power analysis, predictive relevance and GoF index. Proceedings of the 17th Americas Conference on Information Systems (AMCIS2011). Detroit: Association for Information Systems.

Aoki, M. (2000). What are institutions: how should we approach them. Stanford University Working Papers, 15.

Balcerzak, A.P. (2020). Quality of institutions in the European Union countries: application of TOPSIS based on entropy measure for objective weighting. Acta Polytechnica Hungarica, 17(1). doi:10.12700/APH.17.1.2020.1.6.

Bardhan, P. (2005). Institutions matter, but which ones. Economics of Transition and Institutional Change, 13(3). doi:10.1111/j.1468-0351.2005.00229.x.

Borkowski, M. (2020). Economic security of Polish Voivodeships: measuring the concept. Studia Prawno-Ekonomiczne, 114. doi:10.26485/ SPE/2020/114/11.

Boudreaux, K. (2005). The role of property rights as an institution: implications for development policy. Mercatus Policy Series Policy Primer, 2. doi:10.2139/ ssrn.1336664. 
Boudreaux, K., \& Aligica, P.D. (2008). Paths to property: approaches to institutional change in international development. London: Institute of Economic Affairs.

Cao, L. (2012). Informal institutions and property rights. Faculty Publications, 1427.

Chang, H.-J., \& Evans, P. (2005). The role of institutions in economic change. In S. De Paula, \& G. Dymski (Eds.), Reimagining growth: towards a renewal of development theory. London: Zed.

Chin, W.W. (2010). How to write up and report PLS analyses. In V. Esposito Vinzi, W. Chin, J. Henseler, \& H. Wang (Eds.), Handbook of partial least squares. Berlin-Heidelberg: Springer. doi:10.1007/978-3-540-32827-8_29.

Ciborowski, R.W., \& Skrodzka, I. (2019). International technology transfer, innovation and economic development of European Union countries. European Research Studies Journal, 22. doi:10.35808/ersj/1481.

Ciborowski, R.W., Gruszewska, E., \& Meredyk, K.S. (2017). Selected problems of economic theory. Optimum. Studia Ekonomiczne, 5(89). doi:10.15290/ ose.2017.05.89.01.

Commons, J.R. (1924). Legal foundations of capitalism. New York: Macmillan.

Davison, A., \& Hinkley, D. (1997). Bootstrap methods and their application. Cambridge: Cambridge University Press. doi:10.1017/CBO9780511802843.

De Rosa, D., \& Malyshev, N. (2008). Regulatory institutions: a blueprint for the Russian Federation. OECD Working Paper, 10.doi: 10.2139/ssrn.1141547.

Deakin, S., Gindis, D., Hodgson, G.M., Huang, K., \& Pistor, K. (2017). Legal institutionalism: capitalism and the constitutive role of law. Journal of Comparative Economics, Institutions and Economic Change, 45(1). doi:10.1016/j. jce.2016.04.005.

Demsetz, H. (1974). Toward a theory of property rights. In C. Gopalakrishnan (Ed.), Classic papers in natural resource economics. London: Palgrave Macmillan. doi:10.1057/9780230523210_9.

Dicey, A.V. (1979). An introduction to the study of the law of the constitution. London: Palgrave Macmillan. doi:10.1007/978-1-349-17968-8.

Dobler, C. (2011). The impact of formal and informal institutions on economic growth. Frankfurt am Main-Berlin-Bern-Bruxelles-New York-Oxford-Wien: Peter Lang. doi:10.3726/978-3-653-00883-8.

Dworkin, R.M. (1967). The model of rules. The University of Chicago Law Review, 35(1). doi:10.2307/1598947.

Esposito Vinzi, V., Trinchera, L., \& Amato, S. (2010). PLS path modeling: from foundations to recent developments and open issues for model assessment and improvement. In V. Esposito Vinzi, W. Chin, J. Henseler, \& H. Wang (Eds.), Handbook of partial least squares. Berlin-Heidelberg: Springer. doi:10.1007/978-3-540-32827-8_3.

Faundez, J. (2016). Douglass North's theory of institutions: lessons for law and development. Hague Journal on the Rule of Law, 8(2). doi:10.1007/ s40803-016-0028-8. 
Ferrara, A.R. \& Nisticò, R. (2019). Does institutional quality matter for multidimensional well-being inequalities: insights from Italy. Social Indicators Research, 145(3). doi:10.1007/s11205-019-02123-x.

Fiedor, B. (2015). Instytucje formalne i nieformalne w ksztaltowaniu trwałego rozwoju. Studia i Prace Wydziatu Nauk Ekonomicznych i Zarządzania Uniwersytetu Szczecińskiego, 40. doi:10.18276/sip.2015.40/2-07.

Fraser Institute. (2020). Economic freedom. Retrieved 20.03.2021 from https:// www.fraserinstitute.org.

Gancarczyk, M. (2002). Instytucja a organizacja w nowej ekonomii instytucjonalnej. Gospodarka Narodowa, 176(5-6). doi:10.33119/GN/113844.

Geisser, S. (1974). A predictive approach to the random effect model. Biometrika, 61(4). doi:10.2307/2334290.

Gruszewska, E. (2011). Dezintegracja w zinstytucjonalizowanym świecie. Ekonomia i Prawo. Economics and Law, 7(1). doi:10.12775/eip.2011.003.

Gruszewska, E. (2013a). Instytucje a proces tworzenia kapitatu w Polsce. Białystok: Uniwersytet w Białymstoku.

Gruszewska, E. (2013b). Instytucje nieformalne w teorii F.A. Hayeka. Ekonomia. Economics, 4(25).

Gruszewska, E. (2017). Instytucje formalne i nieformalne: skutki antynomii. Prace Naukowe Uniwersytetu Ekonomicznego we Wroctawiu, 493. doi:10.15611/ pn.2017.493.03.

Gruszewska, E. (2020). Ekonomiczne aspekty praw własności: perspektywa instytucjonalna. In R. Przygodzka, \& E. Gruszewska (Eds.), Instytucjonalne i strukturalne aspekty rozwoju rolnictwa i obszarów wiejskich: księga poświęcona pamięci dr hab. Adama Sadowskiego Profesora Uniwersytetu w Biatymstoku. Białystok: Uniwersytet w Białymstoku. doi:10.15290/isarrow.2020.01.

Hair, Jr., J.F., Hult, G.T.M., Ringle, C.M., \& Sarstedt, M. (2017). A primer on partial least squares strucutal equation modeling (PLS-SEM). Los AngelesLondon-New Delhi-Singapore-Washington-Melbourne: SAGE.

Hayek, F.A. (1978). Law, legislation and liberty: rules and order. Chicago: University of Chicago Press.

Heritage Foundation. (2020). Index of economic freedom. Retrieved 20.03.2021 from https: //www.heritage.org.

Hodgson, G.M. (2006). What are institutions. Journal of Economic Issues, 40(1). doi:10.1080/00213624.2006.11506879.

Höpner, M. (2005). What connects industrial relations and corporate governance: explaining institutional complementarity. Socio-Economic Review, 3(2). doi:10.1093/SER/mwi014.

Howard-Hassmann, R.E. (2013). Reconsidering the right to own property. Journal of Human Rights, 12(2). doi:10.1080/14754835.2013.784667.

Iwanek, M., \& Wilkin, J. (1997). Instytucje i instytucjonalizm w ekonomii. Warszawa: Uniwersytet Warszawski.

Jütting, J. (2003). Institutions and development: a critical review. OECD Development Centre Working Papers, 210. doi:10.1787/341346131416. 
Kaufmann, D., Kraay, A., \& Mastruzzi, M. (2011). The worldwide governance indicators: methodology and analytical issues. Hague Journal on the Rule of Law, 3(2). doi:10.1017/S1876404511200046.

Koroso, N.H., Zevenbergen, J.A., \& Lengoiboni, M. (2019). Land institutions' credibility: analyzing the role of complementary institutions. Land Use Policy, 81. doi:10.1016/j.landusepol.2018.11.026.

Kunčič, A. (2014), Institutional quality dataset. Journal of Institutional Economics, 10(1). doi:10.1017/S1744137413000192.

Kwaśnicki, W. (2009). Rządy prawa a rozwój gospodarczy. Prace Naukowe Uniwersytetu Ekonomicznego we Wroctawiu. Ekonomia, 3(74).

Levi-Faur, D. (2010). Regulation \& regulatory governance. Jerusalem Papers in Regulation \& Governance, 1.

Lohmöller, J.-B. (1989). Latent variable path modeling with partial least squares. Berlin: Physica-Verlag. doi:10.1007/978-3-642-52512-4.

Marcinkiewicz, J. (2013). Procesy globalizacji a poziom rozwoju Giełdy Papierów Wartościowych w Warszawie: model miękki. Zarządzanie i Finanse, $11(1)$.

Medina-Morala, E., \& Montes-Gan, V.J. (2018). Economic freedom, good governance and the dynamics of development. Journal of Applied Economics, 21(1). doi:10.1080/15140326.2018.1526873.

Mierzyńska, D. (2011). Socioeconomic well-being: soft model. Acta Universitatis Lodziensis. Folia Oeconomica, 255.

Miller, R.G. (1974). The jackknife: a review. Biometrika, 6l(1). doi:10.2307/2334280.

Misiewicz, E.I. (2013). Działalność innowacyjna a rozwój gospodarczy województw Polski. Zarządzanie i Finanse, 3(2).

Misiewicz, E.I., Roszkowska, E., \& Rogowski, J. (2019). Ocena poziomu ładu gospodarczego województw Polski w 2015 r. Optimum. Economic Studies, 3(97). doi:10.15290/oes.2019.03.97.01.

Monecke, A., \& Leisch, F. (2012). semPLS: structural equation modeling using partial least squares. Journal of Statistical Software, 48(3). doi:10.18637/jss. v048.i03.

Murphy, R. (2016). A comment on "Measuring economic freedom: a comparison of two major sources". Journal of Private Enterprise, 31(3).

Myrdal, G. (1978). Institutional economics. Journal of Economic Issues, 12(4). doi:10.1080/00213624.1978.11503577.

North, D.C. (1990). Institutions, institutional change, and economic performance. Cambridge: Cambridge University Press. doi:10.1017/CBO9780511808678.

North, D.C. (1991). Institutions. The Journal of Economic Perspectives, 5(1). doi:10.1257/jep.5.1.97.

North, D.C. (1994a). Economic performance through time. The American Economic Review, 84(3).

North, D.C. (1994b). The historical evolution of polities. International Review of Law and Economics, 14(4). doi:10.1016/0144-8188(94)90022-1. 
Ogus, A. (2002). Regulatory institutions and structures. Annals of Public and Cooperative Economics, 73(4). doi:10.1111/1467-8292.00208.

Ostrom, E. (2003). How types of goods and property rights jointly affect collective action. Journal of Theoretical Politics, 15(3). doi:10.1177/09516928030 15003002 .

Ott, J. (2018). Measuring economic freedom: better without size of government. Social Indicators Research, 135(2). doi:10.1007/sl1205-016-1508-x.

Owczarczuk, M. (2013). Property rights as a factor of foreign direct investment: the case of Poland. Oeconomia Copernicana, 4(2). doi:10.12775/ OeC.2013.015.

Perło, D. (2014). Modelowanie zrównoważonego rozwoju regionów. Białystok: Trans Humana.

Perło, D., \& Roszkowska, E. (2017). The application of soft modelling and TOPSIS method for the analysis of competitiveness of companies in urban functional areas in Poland. Optimum. Studia Ekonomiczne, 5(89). doi:10.15290/ ose.2017.05.89.05.

Procházka, P., \& Čermáková, K. (2015). Influence of selected institutional factors on the economic growth: case open markets. Procedia Economics and Finance, 30. doi:10.1016/S2212-5671(15)01319-2.

Property Rights Alliance. (2020). International property rights index. Retrieved 20.03.2021 from https://www.propertyrightsalliance.org.

Ratajczak, M. (2011). Popularność ekonomii instytucjonalnej: moda czy trwała zmiana. Zeszyty Naukowe. Polskie Towarzystwo Ekonomiczne, 9.

Riker, W.H., \& Ordeshook, P.C. (1973). An introduction to positive political theory. Englewood Cliffs: Prentice-Hall.

Rocki, M. (1998). Miękkie wskaźniki stanu gospodarki. Prace i Materiaty Instytutu Rozwoju Gospodarczego SGH, 60.

Rodrik, D. (2007). One economics, many recipes: globalization, institutions, and economic growth. Princeton-Oxford: Princeton University Press. doi:10.2307/j. ctvem4jbh.

Rodrik, D., Subramanian, A., \& Trebbi, F. (2004). Institutions rule: the primacy of institutions over geography and integration in economic development. Journal of Economic Growth, 9. doi:10.1023/B:JOEG.0000031425.72248.85.

Rogowski, J. (1990). Modele miękkie: teoria i zastosowanie w badaniach ekonomicznych. Białystok: Dział Wydawnictw Filii UW.

Rossmanith, A. (2019). Praworządność w perspektywie zasady podtrzymywania oraz pogłębiania komunikacji między ludźmi. Acta Universitatis Lodziensis. Folia Iuridica, 87. doi:10.18778/0208-6069.87.09.

Sanchez, G. (2013). PLS path modeling with R. Retrieved 20.03.2021 from http:// www.gastonsanchez.com.

Sanchez, G., Trinchera, L., \& Russolillo, G. (2014). Introduction to the R package plspm. Retrieved 20.03.2021 from https://mran.microsoft.com.

Schlager, E., \& Ostrom, E. (1992). Property rights regimes and natural resources: a conceptual analysis. Land Economics, 68(3). doi:10.2307/3146375. 
Sellin, N., \& Versand, O. (1995). Partial least squares modeling in research on educational achievement. In W. Bos, \& R.H. Lehmann (Eds.), Reflections on educational achievement: papers in honour of T. Neville Postlethwaite. New York: Waxmann Münster.

Shchegolev, I., \& Hayat, A. (2018). Institutional quality, governance and economic growth: evidence from former Soviet countries. Journal of Advances in Economics and Finance, 3(4). doi:10.22606/jaef.2018.34002.

Skrodzka, I. (2015). Kapitat ludzki polskich województw: koncepcja pomiaru. Białystok: Uniwersytet w Białymstoku.

Skrodzka, I. (2016). Knowledge-based economy in the European Union: cross-country analysis. Statistics in Transition, 17(2). doi:10.21307/ stattrans-2016-019.

Stiglitz, J.E. (2000). Economics of the Public Sector, New York: W.W. Norton \& Company.

Stone, M. (1974). Cross-validatory choice and assessment of statistical predictions. Journal of the Royal Statistical Society. Series B (Methodological), 36(2). doi:10.1111/j.2517-6161.1974.tb00994.x.

Tajima, K. (2007). The theory of institutions and collective action in Adam Smith's Theory of Moral Sentiments. The Journal of Socio-Economics, 36(4). doi:10.1016/j.socec.2006.12.015.

Veblen, T.B. (1924). Absentee ownership and business enterprise in recent times: the case of America. London: Allen \& Unwin.

Veblen, T.B. (2016). The theory of the leisure class. Scotts Valley: CreateSpace Independent Publishing Platform.

Vitola, A., \& Šenfelde, M. (2015). The role of institutions in economic performance. Verslas: Teorija ir Praktika, 16(3). doi:10.3846/btp.2015.498.

Voigt, S. (2013). How (not) to measure institutions. Journal of Institutional Economics, 9(1). doi:10.1017/S1744137412000148.

Wang, S. (2002). Defective institutions and their consequences: lesson from China, 1980-1993. Communist and Post-Communist Studies, 35(2). doi:10.1016/S0967-067X(02)00004-1.

Wilkin, J. (2016). Instytucjonalne i kulturowe podstawy gospodarowania. Warszawa: Scholar.

Williamson, C. (2011). The two sides of De Soto: property rights, land titling, and development. In E. Chamlee-Wright (Ed.), The annual proceedings of the wealth and well-being of nations. Beloit: Beloit College Press.

Williamson, O.E. (1985). The economic insitutions of capitalism: firms, markets, relational contrating. New York: Free Press.

Williamson, O.E. (2000). The new institutional economics: taking stock, looking ahead. Journal of Economic Literature, 38(3). doi:10.1257/jel.38.3.595.

Windholz, E., \& Hodge, G. (2012). Conceptualising social and economic regulation: implications for modern regulators and regulatory activity. Monash University Law Review, 2(38). 
Wold, H. (1980a). Model construction and evaluation when theoretical knowledge is scarce. In J. Kmenta, \& J.B. Ramsey (Eds.), Evaluation of econometric models. New York: Academic Press.

Wold, H. (1980b). Soft modelling: intermediate between traditional model building and data analysis. Banach Center Publications, 6(1).

World Bank. (2020) The worldwide governance indicators (WGI). Retrieved 20.03.2021 from https://info.worldbank.org.

Wu, W.-L. (2017). Institutional quality and air pollution: international evidence. International Journal of Business and Economics, 16(1).

Zhuravlev, S. (2017). Law as a method for constituting (defining) social life in the successful society. The European Proceedings of Social \& Behavioral Sciences, doi:10.15405/epsbs.2017.01.101.

\section{Acknowledgements}

Author contributions: author has given an approval to the final version of the article.

Funding: this research was funded by the author's own sources. 


\section{Appendix}

Table 1.

Bundles of property rights associated with a position in relation to the "full owner"

\begin{tabular}{lccccc}
\hline Specification & Full owner & Proprietor & Authorized claimant & Authorized user & Authorized entrant \\
\hline access & + & + & + & + & + \\
withdrawal & + & + & & & \\
management & + & + & & \\
exclusion & + & & & \\
alienation & + & & & & \\
\hline
\end{tabular}

Source: Ostrom (2003, p. 251).

Table 2.

Diagnostic indicators of latent variables in the soft model

\begin{tabular}{|c|c|c|c|c|}
\hline $\begin{array}{c}2^{\text {nd }} \text { order latent } \\
\text { variable }\end{array}$ & $\begin{array}{l}1^{\text {st }} \text { order latent } \\
\text { variable }\end{array}$ & & Diagnostic variables & Source of data \\
\hline \multirow{15}{*}{ FORM } & \multirow[t]{5}{*}{ LEG } & $\mathrm{L}_{1}$ & rule of law & World Bank \\
\hline & & $\mathrm{L}_{2}$ & judicial independence & \\
\hline & & $\mathrm{L}_{3}$ & impartial courts & Fraser Institute \\
\hline & & $\mathrm{L}_{4}$ & integrity of the legal system & \\
\hline & & $\mathrm{L}_{5}$ & judicial effectiveness & Heritage Foundation \\
\hline & \multirow[t]{5}{*}{ PR } & $\mathrm{P}_{1}$ & protection of property rights & Fraser Institute \\
\hline & & $\mathrm{P}_{2}$ & property rights & Heritage Foundation \\
\hline & & $\mathrm{P}_{3}$ & property rights protection & \multirow{3}{*}{ Property Rights Alliance } \\
\hline & & $\mathrm{P}_{4}$ & physical property rights protection & \\
\hline & & $\mathrm{P}_{5}$ & intellectual property rights protection & \\
\hline & \multirow[t]{5}{*}{ REG } & $\mathrm{R}_{1}$ & government effectiveness & \multirow{3}{*}{ World Bank } \\
\hline & & $\mathrm{R}_{2}$ & regulatory quality & \\
\hline & & $\mathrm{R}_{3}$ & sound money & \\
\hline & & $\mathrm{R}_{4}$ & labour market regulations & \multirow[t]{2}{*}{ Fraser Institute } \\
\hline & & $\mathrm{R}_{5}$ & business regulations & \\
\hline
\end{tabular}

Source: Own preparation based on: Fraser Institute (2020), Heritage Foundation (2020), Property Rights Alliance (2020), World Bank (2020). 
Table 3.

Inner model estimation

\begin{tabular}{|c|c|c|c|c|c|c|}
\hline Latent variable & Indicator & Weight & Standard deviation & Factorial loading & Standard deviation & $\mathrm{R}^{2}$ \\
\hline \multirow[t]{5}{*}{ LEG } & $\mathrm{L}_{1}$ & 0.256 & 0.012 & 0.955 & 0.020 & 0.912 \\
\hline & $\mathrm{L}_{2}$ & 0.253 & 0.009 & 0.961 & 0.024 & 0.924 \\
\hline & $\mathrm{L}_{3}$ & 0.252 & 0.010 & 0.929 & 0.032 & 0.864 \\
\hline & $\mathrm{L}_{4}$ & 0.206 & 0.012 & 0.836 & 0.055 & 0.699 \\
\hline & $\mathrm{L}_{5}$ & 0.167 & 0.016 & 0.630 & 0.058 & 0.397 \\
\hline \multirow[t]{5}{*}{ PR } & $\mathrm{P}_{1}$ & 0.246 & 0.009 & 0.975 & 0.028 & 0.950 \\
\hline & $\mathrm{P}_{2}$ & 0.151 & 0.019 & 0.665 & 0.086 & 0.442 \\
\hline & $\mathrm{P}_{3}$ & 0.246 & 0.012 & 0.980 & 0.027 & 0.960 \\
\hline & $\mathrm{P}_{4}$ & 0.230 & 0.009 & 0.927 & 0.038 & 0.859 \\
\hline & $\mathrm{P}_{5}$ & 0.224 & 0.012 & 0.921 & 0.032 & 0.848 \\
\hline \multirow[t]{5}{*}{ REG } & $\mathrm{R}_{1}$ & 0.295 & 0.014 & 0.939 & 0.018 & 0.882 \\
\hline & $\mathrm{R}_{2}$ & 0.297 & 0.010 & 0.966 & 0.033 & 0.933 \\
\hline & $\mathrm{R}_{3}$ & 0.174 & 0.016 & 0.689 & 0.048 & 0.474 \\
\hline & $\mathrm{R}_{4}$ & 0.141 & 0.015 & 0.573 & 0.056 & 0.328 \\
\hline & $\mathrm{R}_{5}$ & 0.274 & 0.011 & 0.860 & 0.029 & 0.739 \\
\hline \multirow[t]{15}{*}{ FORM } & $\mathrm{L}_{1}$ & 0.089 & 0.003 & 0.952 & 0.024 & 0.907 \\
\hline & $\mathrm{L}_{2}$ & 0.089 & 0.003 & 0.947 & 0.026 & 0.897 \\
\hline & $\mathrm{L}_{3}$ & 0.088 & 0.005 & 0.936 & 0.034 & 0.876 \\
\hline & $\mathrm{L}_{4}$ & 0.074 & 0.004 & 0.783 & 0.045 & 0.613 \\
\hline & $\mathrm{L}_{5}$ & 0.058 & 0.006 & 0.626 & 0.054 & 0.392 \\
\hline & $\mathrm{P}_{1}$ & 0.090 & 0.004 & 0.963 & 0.029 & 0.927 \\
\hline & $\mathrm{P}_{2}$ & 0.057 & 0.007 & 0.614 & 0.068 & 0.377 \\
\hline & $\mathrm{P}_{3}$ & 0.090 & 0.003 & 0.966 & 0.022 & 0.934 \\
\hline & $\mathrm{P}_{4}$ & 0.086 & 0.003 & 0.918 & 0.032 & 0.844 \\
\hline & $\mathrm{P}_{5}$ & 0.083 & 0.005 & 0.888 & 0.036 & 0.789 \\
\hline & $\mathrm{R}_{1}$ & 0.088 & 0.005 & 0.942 & 0.034 & 0.887 \\
\hline & $\mathrm{R}_{2}$ & 0.089 & 0.003 & 0.951 & 0.036 & 0.905 \\
\hline & $\mathrm{R}_{3}$ & 0.055 & 0.005 & 0.586 & 0.064 & 0.343 \\
\hline & $\mathrm{R}_{4}$ & 0.046 & 0.004 & 0.485 & 0.050 & 0.235 \\
\hline & $\mathrm{R}_{5}$ & 0.082 & 0.003 & 0.871 & 0.024 & 0.759 \\
\hline
\end{tabular}

Source: Own preparation.

Table 4.

Measures of uniformity of latent variables

\begin{tabular}{lcccc}
\hline Latent variable & Type of indicators & Number of indicators & Cronbach's alpha & Dillion-Goldstein's rho \\
\hline LEG & 5 & 0.915 & 0.939 \\
PR & reflective & 5 & 0.938 & 0.955 \\
REG & 5 & 0.871 & 0.909 \\
FORM & 15 & 0.968 & 0.973 \\
\hline
\end{tabular}

Source: Own preparation. 
Table 5.

Ranking of OECD countries for 2017 in terms of estimated values of latent variables

\begin{tabular}{|c|c|c|c|c|c|c|c|c|}
\hline Country & LEG & R. & PR & R. & REG & R. & FORM & R. \\
\hline Finland & 1.449 & 1. & 1.518 & 1. & 0.904 & 6. & 1.335 & 1. \\
\hline Switzerland & 1.039 & 5. & 1.412 & 2. & 1.435 & 2. & 1.321 & 2. \\
\hline New Zealand & 1.167 & 3. & 1.063 & 6. & 1.459 & 1. & 1.246 & 3. \\
\hline The Netherland & 1.252 & 2. & 1.119 & 3. & 1.187 & 3. & 1.211 & 4. \\
\hline United Kingdom & 0.958 & 6. & 1.114 & 4. & 0.767 & 11. & 0.983 & 5. \\
\hline Canada & 0.860 & 8. & 0.982 & 7. & 1.002 & 5. & 0.970 & 6. \\
\hline Australia & 0.900 & 7. & 0.946 & 8. & 0.878 & 9. & 0.932 & 7. \\
\hline Sweden & 1.062 & 4. & 0.857 & 10. & 0.740 & 12. & 0.912 & 8. \\
\hline USA & 0.707 & 13. & 0.878 & 9. & 1.058 & 4. & 0.898 & 9. \\
\hline Denmark & 0.823 & 10. & 0.794 & 12. & 0.885 & 8. & 0.853 & 10. \\
\hline Japan & 0.603 & 16. & 1.110 & 5. & 0.644 & 13. & 0.820 & 11. \\
\hline Norway & 0.851 & 9. & 0.451 & 17. & 0.831 & 10. & 0.709 & 12. \\
\hline Germany & 0.620 & 15. & 0.462 & 16. & 0.903 & 7. & 0.661 & 13. \\
\hline Luxembourg & 0.592 & 17. & 0.638 & 13. & 0.582 & 14. & 0.613 & 14. \\
\hline Austria & 0.784 & 11. & 0.850 & 11. & 0.083 & 18. & 0.612 & 15. \\
\hline Iceland & 0.762 & 12. & 0.411 & 18. & 0.582 & 15. & 0.597 & 16. \\
\hline Ireland & 0.649 & 14. & 0.467 & 15. & 0.537 & 16. & 0.565 & 17. \\
\hline Belgium & 0.218 & 20. & 0.489 & 14. & 0.011 & 19. & 0.263 & 18. \\
\hline Estonia & 0.125 & 21. & 0.021 & 21. & 0.358 & 17. & 0.156 & 19. \\
\hline France & 0.242 & 19. & 0.308 & 19. & -0.143 & 20. & 0.153 & 20 . \\
\hline Israel & 0.336 & 18. & 0.119 & 20. & -0.206 & 21. & 0.095 & 21. \\
\hline Chile & -0.343 & 22. & -0.365 & 22. & -0.501 & 27. & -0.409 & 22. \\
\hline Korea Republic & -0.452 & 23. & -0.444 & 23. & -0.288 & 23. & -0.413 & 23. \\
\hline Czech Republic & -0.554 & 25. & -0.567 & 24. & -0.443 & 26. & -0.532 & 24. \\
\hline Lithuania & -0.552 & 24. & -0.797 & 26. & -0.207 & 22. & -0.550 & 25. \\
\hline Portugal & -0.715 & 27. & -0.579 & 25. & -0.396 & 25. & -0.585 & 26. \\
\hline Spain & -0.631 & 26. & -0.907 & 28. & -0.596 & 28. & -0.736 & 27. \\
\hline Latvia & -0.784 & 28. & -1.311 & 32. & -0.386 & 24. & -0.872 & 28. \\
\hline Slovenia & -0.857 & 29. & -1.155 & 30. & -0.885 & 30. & -0.994 & 29. \\
\hline Slovakia & -1.516 & 34. & -0.840 & 27. & -1.026 & 31. & -1.146 & 30. \\
\hline Poland & -1.345 & 30. & -1.373 & 33. & -0.714 & 29. & -1.189 & 31. \\
\hline Italy & -1.366 & 31. & -1.112 & 29. & -1.219 & 33. & -1.253 & 32. \\
\hline Hungary & -1.415 & 33. & -1.572 & 35. & -1.040 & 32. & -1.385 & 33. \\
\hline Turkey & -1.899 & 35. & -1.557 & 34. & -1.987 & 34. & -1.848 & 34. \\
\hline Mexico & -2.175 & 36. & -1.242 & 31. & -2.510 & 36. & -1.988 & 35. \\
\hline Greece & -1.394 & 32. & -2.191 & 36. & -2.299 & 35. & -2.004 & 36. \\
\hline
\end{tabular}

Source: Own preparation. 


\section{Scheme 1 .}

Formation, evolution and functioning of institutions in the economy

\begin{tabular}{|c|c|c|c|}
\hline $\begin{array}{l}\text { uncertainty; high } \\
\text { transaction costs }\end{array}$ & $\begin{array}{l}\text { implementation or } \\
\text { alternation of } \\
\text { institutions }\end{array}$ & $\begin{array}{l}\text { increasing the } \\
\text { predictability of } \\
\text { human behaviour }\end{array}$ & $\begin{array}{c}\text { transaction costs } \downarrow \\
\text { stability } \uparrow \\
\text { security } \uparrow\end{array}$ \\
\hline
\end{tabular}

Source: Dobler (2011, p. 21).

\section{Scheme 2.}

\section{Selected contemporary classifications of institutional structure}

\begin{tabular}{|c|c|c|}
\hline institutions & & \\
\hline & formal and informal & D.C. North \\
\hline 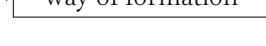 & spontaneous and constituted & F.A. Hayek \\
\hline$\rightarrow \quad$ area of analysis & economic, political, legal, social etc. & J. Jütting \\
\hline$\rightarrow$ frequency of change & $\begin{array}{l}\text { - informal }\left(10^{2} \text { to } 10^{3} \text { years) }\right. \\
\text { - institutional environment (10 to } 10^{2} \text { years) } \\
\text { - governance structures (1 to } 10 \text { years) } \\
\text { - allocation mechanisms (continuous changes) }\end{array}$ & O.E. Williamson \\
\hline form & $\begin{array}{l}\text { - formal and informal norms (processes) } \\
\text { - markets (processes and entities) } \\
\text { - organisations (entities) }\end{array}$ & D.C. North $(+\mathrm{NEI})$ \\
\hline
\end{tabular}

Source: Own preparation based on: Gruszewska (2013b, p. 170), Hayek (1978, p. 37), Jütting (2003, pp. 11-14), North (1991, p. 97), Wilkin (2016, p. 104), Williamson (2000, p. 597).

\section{Scheme 3 .}

Diagram of the soft model applied in the article

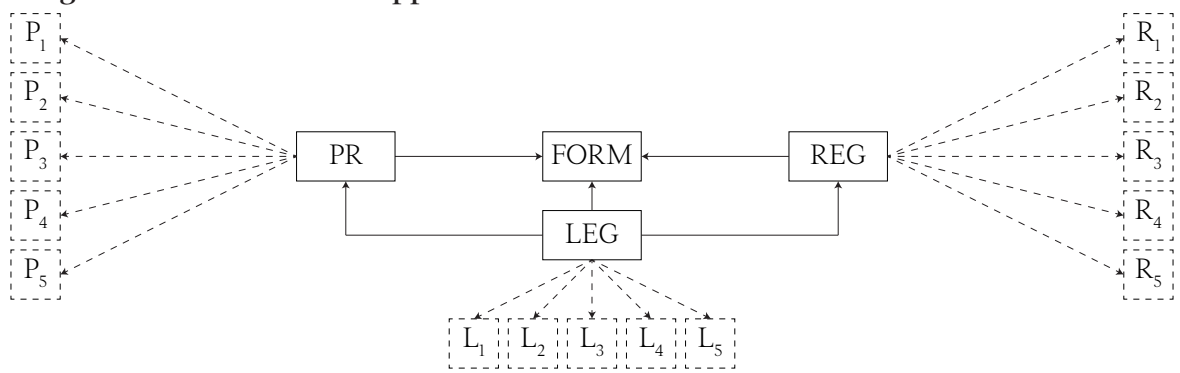

Source: Own preparation. 